\title{
Farming and soil urban occupation in the water quality of Jaboticabal and Cerradinho streams
}

\section{Agricultura e ocupação urbana do solo na qualidade da água dos córregos Jaboticabal e Cerradinho}

\author{
Géssica Aparecida Silveira ${ }^{1}$, Luciana Maria Saran ${ }^{1 \star}$, Wanderley José de Melo', Lucia Maria Carareto Alves \\ "Universidade Estadual Paulista "Júlio de Mesquita Filho"/UNESP, Departamento de Tecnologia, Jaboticabal, SP, Brasil \\ *Corresponding author: Imsaran@fcav.unesp.br \\ Received in December 18, 2015 and approved in September 2, 2016
}

\begin{abstract}
Since the end of the twentieth century, $100 \%$ of the urban sewage from the city of Jaboticabal has been collected by interceptors and routed to a treatment plant. Between 1999 and 2000, studies on the effect of this environmental care showed that it did not efficiently clean up the water from the two streams that run through the city and flow into an agricultural area. This paper focuses on assessing the influence of soil use on the water quality of surface waters from these two streams. The study was conducted 15 years after the implementation of sewage interceptors. The sampling dates were bimonthly at eight points (P1 to P8) in the Cerradinho and Jaboticabal streams, in Jaboticabal (São Paulo State, Brazil). P1 was located at the source of the Jaboticabal stream, P2 was in a farming area, P3, P4 and P5 were in an urban area, and P6, P7 and P8 were in a farming area. The physical and chemical variables of the water were assessed. We compared the ability of microorganisms to metabolize different sources of carbon using the EcoPlate (Biolog). The total phosphorus (TP) concentration exceeded the limit set by the Brazilian legislation as well as values found in previous studies, which was also observed for the chemical oxygen demand. However, the bacterial metabolic profile had no association with urban or farming practices. The results of the analysis indicated the possibility of clandestine discharge of wastewater in the streams studied and the influence of the agricultural soil.
\end{abstract}

Index terms: Leaching; EcoPlate; metabolic profile; water resources.

\begin{abstract}
RESUMO
Desde o final do século vinte, $100 \%$ do esgoto urbano da cidade de Jaboticabal é recolhido por interceptores e conduzido a uma estação de tratamento. Entre 1999 e 2000, estudos sobre o efeito desse cuidado ambiental, mostraram que a coleta de esgoto ainda não tinha sido eficiente para despoluir as águas dos dois córregos que atravessam a cidade e fluem para uma área agrícola. Neste trabalho avalia-se a influência do uso do solo na qualidade da água destes dois córregos. O estudo foi realizado 15 anos após a implantação dos interceptores de esgoto. Durante o ano de 2014, bimestralmente, coletaram-se amostras de água em oito pontos (P1 a P8), dos córregos Cerradinho e Jaboticabal, em Jaboticabal (SP, Brasil). P1 estava localizado na nascente do córrego Jaboticabal; P2 em área agrícola; P3, P4 e P5 em área urbana; P6, P7 e P8 em área agrícola. Foram determinadas variáveis físicas e químicas e a comparação metabólica da população microbiana em diversas fontes de carbono pelo método EcoPlate (Biolog). Em todos os pontos e coletas, o teor de fósforo total excedeu o limite estabelecido pela legislação brasileira, assim como valores encontrados em estudos anteriores, o que também foi observado em relação à demanda química de oxigênio. Entretanto, a população microbiana da água parece não estar sendo alterada pelas atividades urbanas e agrícolas. Os resultados das análises sinalizam à possibilidade de descarga clandestina de águas residuárias nos córregos estudados e à influência do uso agrícola do solo.
\end{abstract}

Termos para indexação: Lixiviação; EcoPlate; perfil metabólico; recursos hídricos.

\section{INTRODUCTION}

Many Brazilian municipalities capture water from surface water sources to supply and launch domestic and industrial effluents in the river basin, resulting in potentially negative impacts on the water quality. At the same time, these water bodies, which are important for the development of agriculture, are negatively impacted by these activities, including contamination by agrochemicals and increased suspension materials. Considering the importance of water in our society and the need to maintain the environmental balance, the study of anthropogenic influences on water quality in water bodies are critical to environmental planning studies for the protection and restoration of areas with great human rural or urban pressure.

Studies on water quality based on physical, chemical and microbiological variables enable quality evolution monitoring in a water body as well as over an 
entire watershed (Medihala et al., 2012; Sahu et al., 2013). Furthermore, water analysis plays an important role in assessing chemicals with concentrations greater than the maximum values established by environmental law, which can cause health problems and environmental impacts (Jabben et al., 2014). Several physical (temperature, dissolved and suspended solid contents, color, transparency and turbidity), chemical (chloride, nitrate, nitrite, ammonia, total phosphorus, soluble reactive phosphorus, $\mathrm{pH}$, electric conductivity, dissolved oxygen, etc.) and microbiological attributes may be used as indicators of water quality.

The traditional methodology for microbial studies has changed because of methods that can show the behavior of a microbial population. EcoPlate (Biolog) is a rapid and convenient method to mainly investigate and estimate the impact of stressors on microbial communities from several environmental sources: soil (Muniz et al., 2014; FloresRentería et al., 2016), water (Patel et al., 2014; Xiao; Tinglin; Haihan, 2015), wastewater from different technologies (Jałowiecki et al., 2016) and many other sources.

Starting from the premise that land use and occupation change the physico-chemical and natural biological processes, resulting in potentially negative impacts on water quality, the aim of this study was to evaluate the influence of human activity on water quality by analyzing the physical and chemical variables as well as the microbial community metabolic profile.

The water bodies studied in this work (Cerradinho and Jaboticabal streams) run through the city of Jaboticabal (São Paulo, Brazil) and move to an agricultural region. Thus, these water sources are areas subjected to pressure by urban activities and agriculture. Historically the streams were sites used to launch domestic raw sewage. At the end of the 1990 s, $100 \%$ of the city sewage started to be collected by receivers along streams and was treated. Borges, Galbiati and Ferraudo (2003) found that sewage interceptors by that time were not enough to de-pollute the streams in urban areas. Consequently, this pollution came to agricultural areas that were located downstream from the urban area. Studies of the riparian forests and areas occupying the banks of streams were carried out over 10 years (Pissarra et al., 2009) and it was observed that the Jaboticabal stream preserved its riparian forests better (47.6\% of APP area) than the Cerradinho stream ( $0.7 \%$ of APP with vegetation). Thus, further studies on the water quality of these water resources and the current influences of the urban and rural human activities were the goals of this work. The results observed after 15 years from the addition of the sewage interceptor can show that the pollution potential of the activities in the running water can also help with planning protection processes and environmental recovery in the region.

\section{MATERIAL AND METHODS}

The study was performed using water samples taken from the Cerradinho and Jaboticabal streams, which are located within the city of Jaboticabal, Northeastern São Paulo State, in Brazil. Both streams belong to the Córrego Rico subwatershed within the drainage area of Mogi-Guaçu and are tributaries of the Mogi-Guaçu River (Pissarra et al., 2009). Six sampling points were set along the Cerradinho and Jaboticabal streams. These water sources run through Jaboticabal city and intersect each other near the city hall, where it is called the Jaboticabal stream, which goes toward the College of Agricultural and Veterinarian Sciences (FCAV/UNESP) downstream of the city. Figure 1 shows the Jaboticabal stream subwatershed. The sampling points (P1 to $\mathrm{P} 8$ ) were distributed as following: P1 was at the Jaboticabal stream source; P2 was at the entrance to Jaboticabal city in the Cerradinho stream; P3, P4 and P5 were located within the urban area after the Cerradinho and Jaboticabal streams intersect; and P6, P7 and P8 were within the agricultural area (FEPE, Education, Research and Extension Farm at FCAV/UNESP). Agricultural practices in this area are from soybean, corn and other crops and have been carried out for 80 years through conventional management. The local soil is classified as Eutroferric Red Latosol - LVef (Oxisol) with a clayey texture.

The samples were collected bimonthly throughout 2014, for a total of six sampling dates in February, April, June, August, October and December represented by D1, D2, D3, D4, D5 and D6, respectively. Monthly rainfall data were obtained from a weather station located in the FCAV (Rolim, 2014). The water samples were collected up to $30 \mathrm{~cm}$ below the surface of the water by adopting the procedures for sampling, storage and preservation of inorganic nonmetallic constituents and aggregate organic constituents (Baker, 2005) described in the Standard Methods for the Examination of Water and Wastewater. The water samples that were collected for microbial activity analysis were collected and stored in amber glass vials, sterilized in an autoclave, transported at 4 to $8{ }^{\circ} \mathrm{C}$ and used immediately.

\section{Physical and chemical variables}

We measured the following variables: $\mathrm{pH}$, electric conductivity (COND), temperature (T), dissolved oxygen (DO), turbidity (TURB), total dissolved solids (TDS) and oxidation-reduction potential or redox potential (ORP) 
at the sampling points with the aid of a multiparameter probe (origin Horiba U52). The chloride content $\left(\mathrm{Cl}^{-}\right)$ was determined by titrimetric precipitation, which is an argentometric method (Askew; Smith, 2005). Ammonia nitrogen $\left(\mathrm{NH}_{4}^{+}\right)$, nitrate $\left(\mathrm{NO}_{3}^{-}\right)$, nitrite $\left(\mathrm{NO}_{2}^{-}\right)$, total phosphorus (TP), soluble reactive phosphorus (SRP) and chemical oxygen demand (COD) were determined by molecular spectroscopy in the visible region with a spectrophotometer SPEC 20D. All analyses were performed in triplicate for each variable. The phenate method was used for $\mathrm{NH}_{4}^{+}$; the colorimetric method was used for $\mathrm{NO}_{2}^{-}$using $\mathrm{N}$-(1-naphthyl)-ethylenediamine dihydrochloride (NED dihydrochloride) to react with the analyte; the reduction method was used for $\mathrm{NO}_{3}^{-}$; the ascorbic acid method was used for TP after digesting the water samples with sulfuric and nitric acids; SRP was also analyzed using the ascorbic acid method after the sample was percolated through a $0.45 \mu \mathrm{m}$ membrane (Askew; Smith, 2005). The closed reflux colorimetric method was used for COD (Baird, 2005).

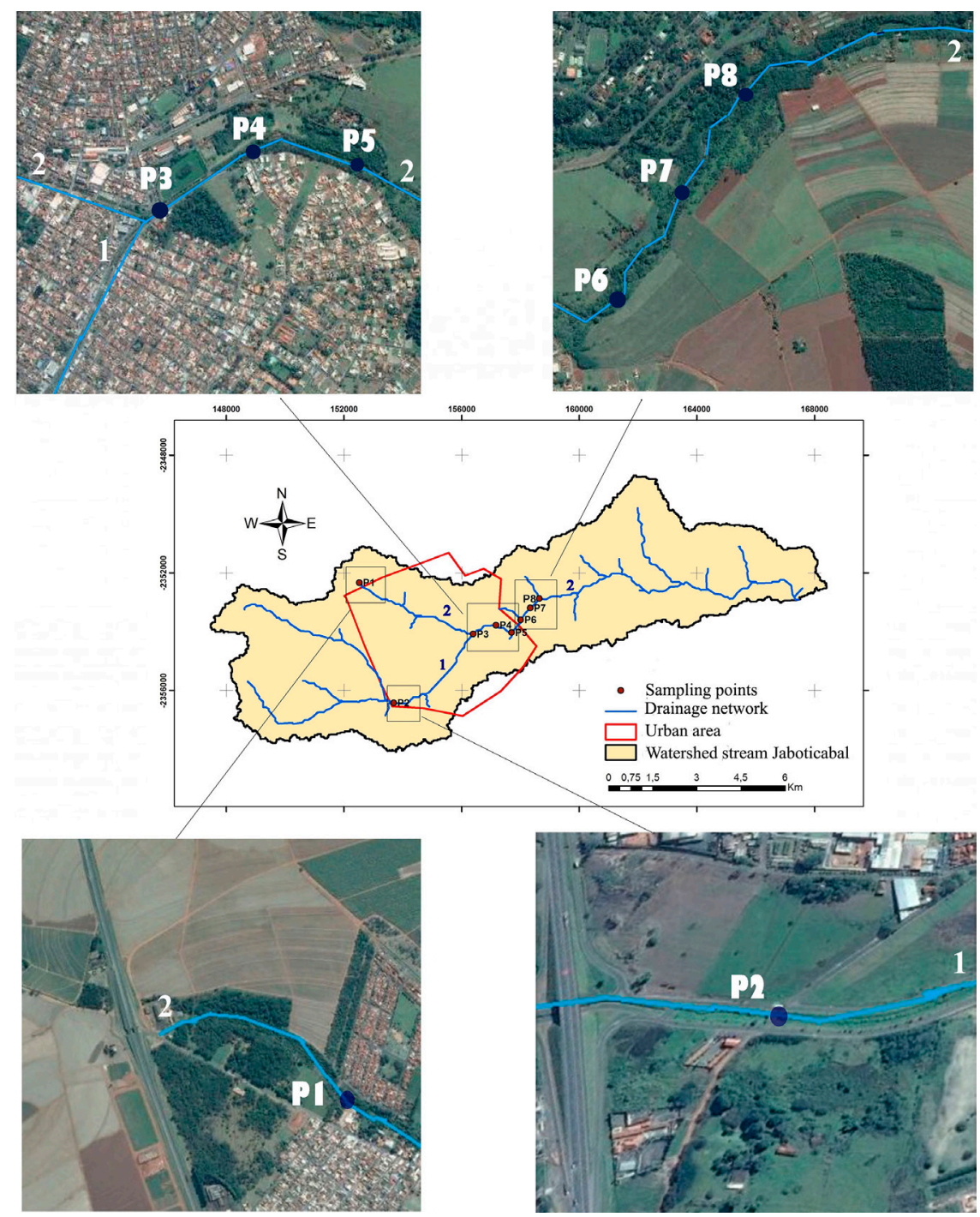

Figure 1: Description of the sampling points on the Jaboticabal stream subwatershed showing the urban and farming area. The blue lines represent tributaries that compose the subwatershed (1 - Cerradinho Stream and 2 - Jaboticabal Stream). The geographical coordinates are: P1 (S - 21.276.88, O - 48.335.39); P2 (S - 21.244.10, O 48.244. 30); P3 (S - 21.256.08, O - 48.295.59); P4 (S - 21.253.31, O - 48.304.77); P5 (S - 21.255.45, O - 48.300.27); P6 (S - 21.249.05, O - 48.295.59); P7 (S - 21.246.38, O - 48.290.10); and P8 (S - 21.245.65, O - 48.289.53). 


\section{Metabolic profile}

The microbial communities in the samples were compared by the type of carbon source that was metabolized using a Biolog EcoPlateTM (Garland; Mills, 1991). This plate contained 31 of the most useful carbon sources for soil community analysis. These 31 carbon sources were repeated 3 times to provide replicates of the data. A purple color formed when the microbes utilized the carbon source. The respiration of the cells in the community reduced a tetrazolium dye that was included with the carbon source. The water samples were distributed on plates under a laminar flux as soon as they arrived at the laboratory. Each of the 96 plate wells were filled with a $130 \mu \mathrm{L}$ aliquot of the sample, which remained at $27{ }^{\circ} \mathrm{C}$ in a biological oxygen demand incubator (BOD incubator) for 5 days. Carbon source consumption was measured in a Molecular Devices Spectramax M2 plate reader at an emission of $590 \mathrm{~nm}$. The readings were taken immediately after the addition of the water samples on the plate (T0) and every $24 \mathrm{~h}$ for 5 consecutive days. Control readings (without the substrate, only water) were subtracted from each substrate reading. The generated data enabled the comparison of the microbial population for each sample with respect to the number of substrates used or the substrate index richness (S), average well color development (AWCD) after $120 \mathrm{~h}$ of incubation, Shannon diversity index $(\mathrm{H})$ and Shannon evenness index (E). AWCD was used as an indicator of the general microbial activity and was assessed as the average optical density across all of the wells in the plate (Zhang et al., 2014). The $\mathrm{H}$ index was calculated from the sum of all of the incubation times and the Shannon Evenness (E) index was calculated from the Shannon-Weiner diversity index $(\mathrm{H})$ and substrate richness $(\mathrm{S})$ index.

\section{Statistical Analysis}

The results of the physical and chemical variables at each water sampling point are presented in the boxplot graphics, which enabled the evaluation of the spatial variability of each studied parameter and a comparison of the different sampling sites. The boxplot of each sampling site was built using the following numbers: minimum value, first quartile (Q1), second quartile (or median, $\mathrm{Q} 2)$, third quartile (Q3) and maximum value. The rule adopted for identifying outliers based on the interquartile range (IQR) was defined as the distance between the first and third quartiles. Thus, any values below Q1 or above Q3 by more than 1.5xIQR were considered outliers. Furthermore, the results of the physical and chemical parameters underwent multivariate principal component analysis (PCA), which is classified as an interdependence technique in which no variable is defined as independent or dependent because the process involves the simultaneous analysis of all variables. This analysis was applied to evaluate the water quality in relation to all variables and identify the possible temporal variations and the most impacted sampling sites. The means of all variables were used, which allowed for the determination of standard values, with a zero mean and variance equal to one (Guedes et al., 2012). The principal component analysis consisted of calculating the eigenvalues and corresponding eigenvectors of a correlation matrix. PCA was performed by selecting the eigenvectors above 1.00, according to Kaiser-Guttman (Jackson, 1993), with the aid of Statistica Software, Version 7 (Statsoft Inc., Tulsa, USA). In this work, as in other studies reported in the literature (Guedes et al., 2012; Pereira-Silva et al., 2011), we adopted eigenvalues above 0.5 . The first two principal components (PC1 and PC2) were used because they had a higher total variation than the original data.

For information on the microbial metabolic profile, primarily by having five absorbance reading times, we performed a mathematical calculation for each substrate using the formula proposed by Hackett and Griffiths (1997), which proposed the use of an equation using data from all of the time points, thereby determining the metabolism and consumption during the entire incubation period. Then, they were submitted to the normalization proposed by Weber et al. (2007). Afterwards, hierarchical clustering heatmaps were generated using "R" software (The R Project for Statistical Computing, 2014) through both the Ward's Method linking method and Euclidean distance between sampling points, as well as for the consumption of the carbon sources.

\section{RESULTS AND DISCUSSION}

\section{Physical and chemical variables}

The results of the physical and chemical parameters were compared to the local conditions and class 2 freshwater quality standards established by the National Council of the Environment (CONAMA) at a resolution of 357/2005 (Brasil, 2005). Figures 2 and 3 show the spatial variation of TP, SRP, $\mathrm{Cl}^{-}, \mathrm{NH}_{4}^{+}, \mathrm{NO}_{2}^{-}, \mathrm{NO}_{3}^{-}, \mathrm{COD}, \mathrm{pH}, \mathrm{ORP}$, electric conductivity, turbidity, DO, TDS and T. Regarding the phosphorus content, TP exceeded the limit established by CONAMA for lotic environments $\left(0.1 \mathrm{mg} \mathrm{L}^{-1}\right)$ at concentrations up to 12 times higher than the limit within a range of 0.27 to $1.25 \mathrm{mg} \mathrm{L}^{-1}$ (Figure 2). There was an increase in the concentration of TP at the sampling points (P6, $\mathrm{P} 7$ and $\mathrm{P} 8)$ near farming areas. The 
location of these sampling points means that the water quality is affected by agricultural activities, due to the proximity of $\mathrm{P} 6$ to sugarcane farming, and also to urban activities upstream. Domestic and industrial effluents, fertilizers and leaching from animal farms are the main anthropogenic sources of phosphorus (Libânio, 2010). According Jian et al. (2016), phosphorus $(\mathrm{P})$ in the soil can be lost to water through two main transportation pathways, overland in surface runoff or eroded soils and vertical leaching with drainage. In most fields, $\mathrm{P}$ loss is predominantly through surface runoff and erosion.
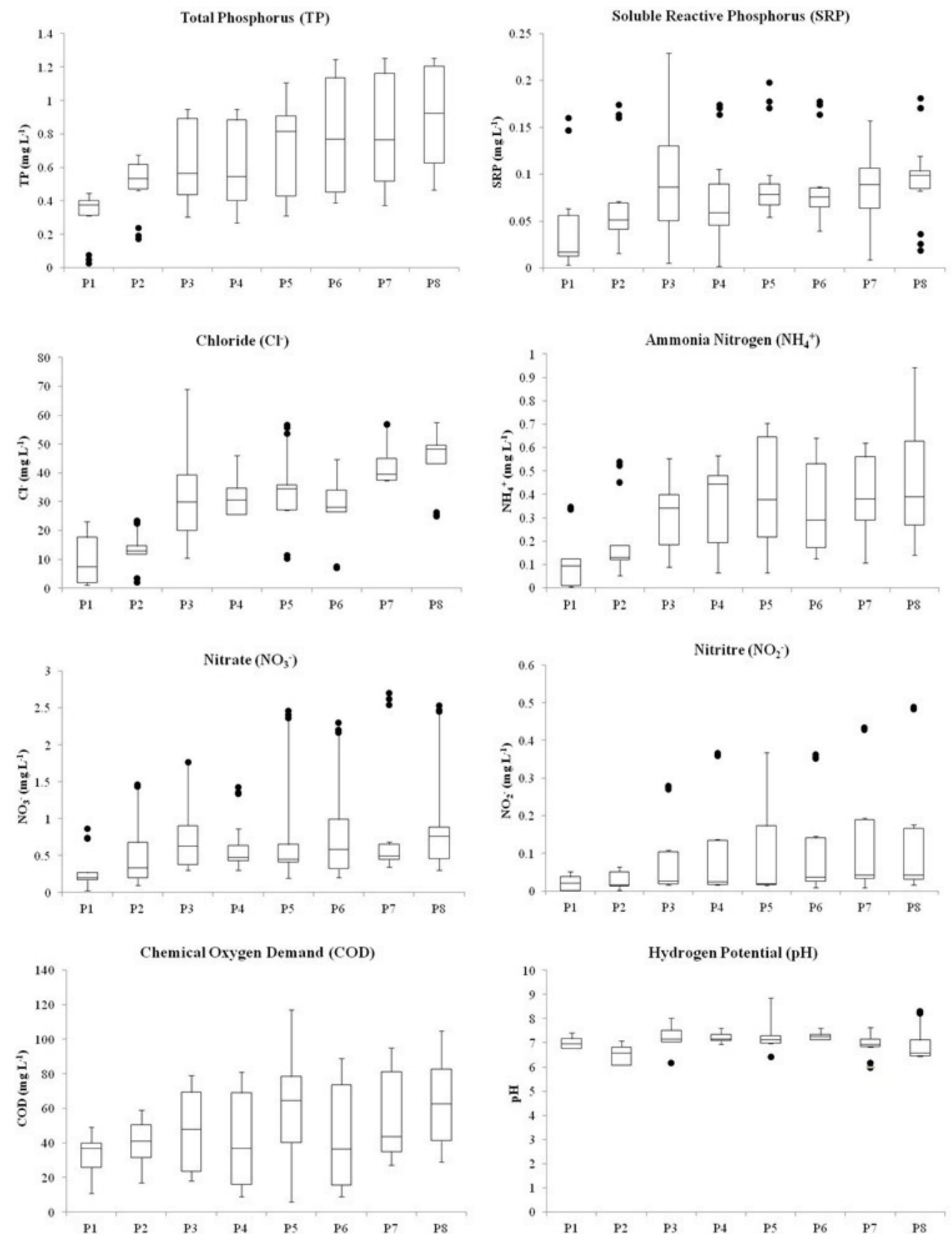

Figure 2: Spatial variation of total phosphorus (TP), soluble reactive phosphorus (SRP), $\mathrm{Cl}, \mathrm{NH}_{4}^{+}, \mathrm{NO}_{2}{ }^{-}, \mathrm{NO}_{3}$, chemical oxygen demand (COD) and $\mathrm{pH}$. 

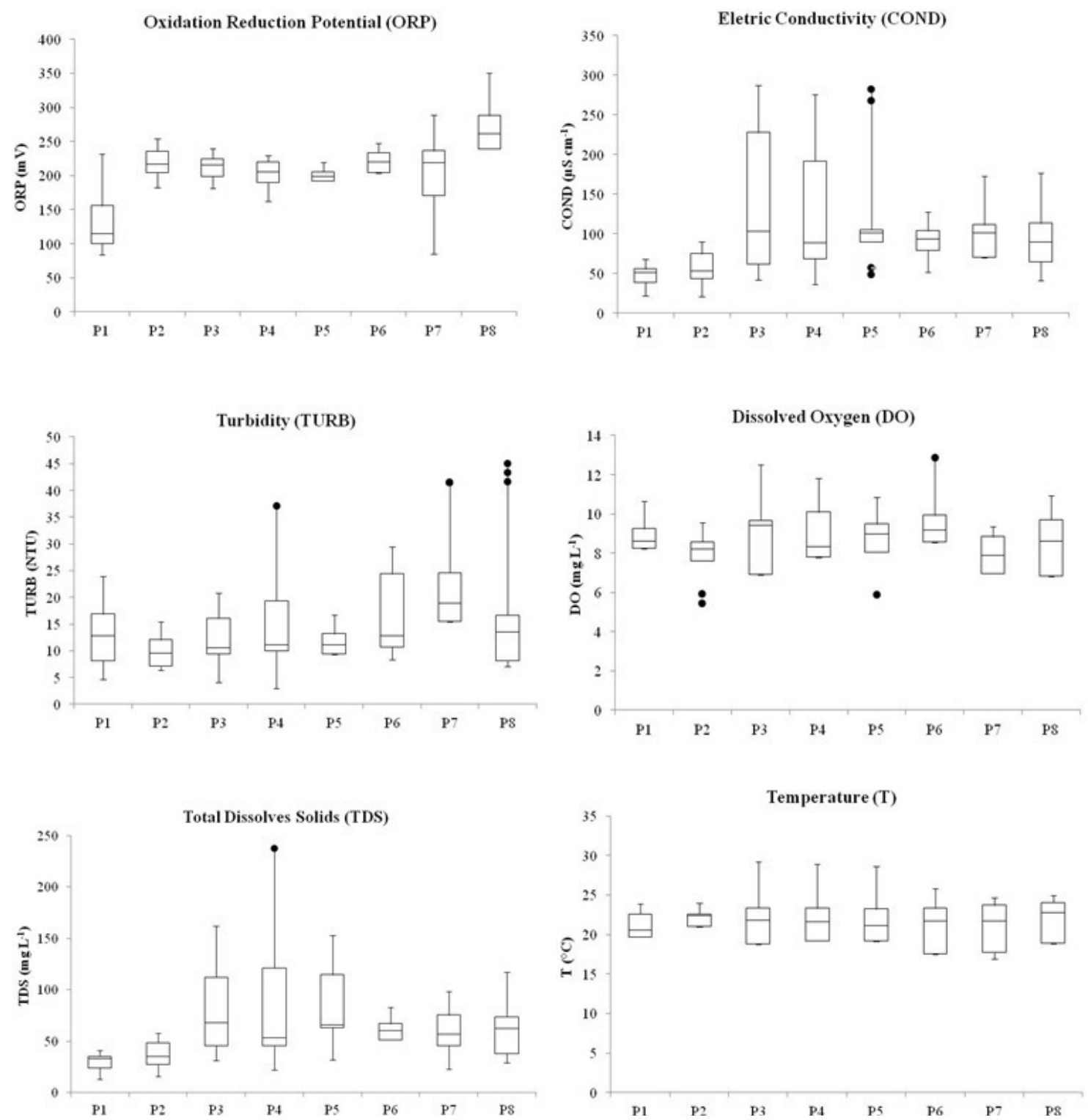

Figure 3: Spatial variation of oxidation-reduction or redox potential (ORP), electric conductivity, turbidity, dissolved oxygen (DO), total dissolved solids (TDS) and temperature (T).

A study conducted in the Cerradinho and Jaboticabal streams between 1999 and 2000 evaluated the effect of the implantation of sewage interceptors as a remediation technique in the urban area of Jaboticabal. In this study the TP concentrations were observed in the range of 0 to $0.243 \mathrm{mg} \mathrm{L}^{-1}$ and were attributed to the discharge of effluents into the sample sites because they were located in areas where phosphate was used to prevent scale formation, inhibit corrosion and improve the efficiency of washing and cleaning (Borges; Galbiati; Ferraudo, 2003).
It should be emphasized that, in the present study, the TP concentrations found at the sampling sites exceeded the concentrations reported by Borges, Galbiati and Ferraudo (2003), indicating that the studied streams continue to be influenced by discharged effluents.

Figure 2 shows that the SRP concentrations increased from $\mathrm{P} 3$, and although the CONAMA resolution of 357/2005 did not establish values for this variable, the limnological point of view, which is the main storage form of phosphorus assimilated by micro-organisms and aquatic plants, made their 
quantification indispensable (Dias; Sipauba-Tavares, 2012). Surplus phosphate in water can propitiate the uncontrolled growth of algae and aquatic plants, which restricts its use for fishing, recreation, industry and drinking consumption due to eutrophication (Sharpley; Wang, 2014). Whereas SRP is the form that is more easily assimilated by algae and macrophytes, which incorporate SRP into their biomass, in unpolluted waters, the ability of phytoplankton and aquatic plants to incorporate SRP results in SRP concentrations less than $0.02 \mathrm{mg} \mathrm{L}^{-1}$ near the surface of the body of water (Libânio, 2010). However, in this study, the median concentration of SRP exceeded $0.02 \mathrm{mg} \mathrm{L}^{-1}$, except at P1, which was located at the source of the Jaboticabal stream in a permanently protected preservation area.

For the $\mathrm{Cl}^{-}$concentrations, $\mathrm{P} 7$ and $\mathrm{P} 8$ reached maximum values of 56.45 and $57.46 \mathrm{mg} \mathrm{L}^{-1}$, respectively (Figure 2). Nevertheless, these values did not exceed the limit established by CONAMA ( $\left.250 \mathrm{mg} \mathrm{L}^{-1}\right)$. Low chloride concentrations are essential for normal cell function. However, high concentrations contaminate freshwater streams and lakes causing damage to aquatic life (Sulaiman et al., 2014). The major anthropogenic sources of $\mathrm{Cl}^{-}$are domestic sewage and the use of agricultural inputs, such as $\mathrm{KCl}$, which is used as a potassium source. Thus, the highest chloride concentrations were observed at points $\mathrm{P} 3, \mathrm{P} 4$ and $\mathrm{P} 5$, which was due to those locations receiving urban influences, and P6, P7 and P8, which were subjected to urban and rural influences.

Regarding the nitrogen, $\mathrm{NH}_{4}^{+}$reached concentrations of $0.94 \mathrm{mg} \mathrm{L}^{-1}$ at P8 (Figure 2) but the ammonia nitrogen concentration never exceeded the maximum limit set by CONAMA (3.7 $\mathrm{mg} \mathrm{L}^{-1}$ at $\left.\mathrm{pH} \leq 7.5\right)$. The main nitrogen anthropogenic sources, are the domestic sewage, where almost all of the nitrogen is in the organic form $(40 \%)$ and as ammonia (60\%), as well as industrial sewage, farm animal sewage and fertilizers (as nitrate) applied to arable land, result in nitrogen being leached by the rain for the watercourses (Libânio, 2010). We observed $\mathrm{NO}_{2}$ concentrations below $0.1 \mathrm{mg} \mathrm{L}^{-1}$ at $\mathrm{P} 1$, which receives an urban influence because it is located at the source of the Jaboticabal stream, which is on the border between an urban area and an area where sugarcane is planted, but this source is protected because it is a permanent preservation area The concentrations at $\mathrm{P} 2$ were below $0.1 \mathrm{mg} \mathrm{L}^{-1}$ too. The maximum concentration of $\mathrm{NO}_{2}{ }^{-}$was observed at $\mathrm{P} 8(0.49$ $\left.\mathrm{mg} \mathrm{L}^{-1}\right)$ and there were high concentrations at P7 $(0.43 \mathrm{mg}$ $\left.\mathrm{L}^{-1}\right)$ and at $\mathrm{P} 5\left(0.37 \mathrm{mg} \mathrm{L}^{-1}\right)$. The high levels of $\mathrm{NO}_{3}^{-}$were observed at P2 (1.38 $\left.\mathrm{mg} \mathrm{L}^{-1}\right)$ and at P3 $\left(1.69 \mathrm{mg} \mathrm{L}^{-1}\right)$, which were located just after the junction of the two streams in a region devoid of a permanent preservation area and prone to flooding. Given the location, these points receive an urban influence and a large volume of rainwater. However, higher concentrations were observed at P7 $\left(2.48 \mathrm{mg} \mathrm{L}^{-1}\right)$ and at P8 (2.62 $\mathrm{mg} \mathrm{L}^{-1}$ ), which are near farming areas (Figure 2). There was an increase in the concentration of $\mathrm{NO}_{3}{ }_{3}^{-}$at points near agricultural areas. However, the concentrations of $\mathrm{NO}_{3}{ }^{-}$and $\mathrm{NO}_{2}{ }^{-}$were lower than the maximum values set by legislation (10.0 and $1.0 \mathrm{mg} \mathrm{L}^{-1}$, respectively). Thus, among the forms of nitrogen studied, there was a predominance of nitrate (an oxidized nitrogen form and essential nutrient for most aquatic organisms) at the expense of nitrite and ammonia nitrogen (a reduced form, present in anaerobic conditions). The nitrite occurs at low concentrations under aerobic conditions such as those found in this study, where we observed DO concentrations close to saturation.

With respect to COD (Figure 2), the maximum values were found at P5 (117 $\left.\mathrm{mg} \mathrm{L}^{-1}\right)$ and at P8 (105 mg $\mathrm{L}^{-1}$ ). The median values for COD were 37 (at $\mathrm{P} 1$ ), 41 (at P2), 48 (at P3), 37 (at P4), 64.5 (at P5), 36.5 (at P6), 43.5 (at P7) and $62.5 \mathrm{mg} \mathrm{L}^{-1}$ (at P8). Borges, Galbiati and Ferraudo (2003) observed a tendency for COD, TP and total nitrogen to increase from the sources to the confluence of the Jaboticabal and Cerradinho streams mainly in the period in which the sewage collectors were not in operation. They obtained the following annual averages for COD: 7.6 and $25.3 \mathrm{mg} \mathrm{L}^{-1}$ at the Cerradinho stream, located $4.7 \mathrm{~km}$ from the source (in a rural) area and $10.5 \mathrm{~km}$ from the source (in an urban area), respectively. They observed at Jaboticabal stream average for COD of 5.4, 22.9, 90.3 and $62.3 \mathrm{mg} \mathrm{L}^{-1}$ in a rural area, at $1.3 \mathrm{~km}$ from the source (in a rural/urban area), at $4.5 \mathrm{~km}$ from the source (in an urban area) and at the confluence of the two streams, respectively. The COD values obtained in the present study compared with the results observed by Borges, Galbiati and Ferraudo (2003) indicated that, despite the installation of the sewage collection system approximately 15 years ago, it is still possible to illegally discharge wastewater into the studied streams.

The $\mathrm{pH}$ of the evaluated points ranged between 6.0 and 8.5, except at $\mathrm{P} 2$, which had a $\mathrm{pH}$ of 5.12 (Figure 2), thus the $\mathrm{pH}$ was below the lower limit set by CONAMA ( $\mathrm{pH}$ between 6 and 9). The median $\mathrm{pH}$ values were between 6.56 and 7.27, indicating a small variation for this parameter. The $\mathrm{pH}$ of the continental waters can vary from 6.7 to 8.6 depending on factors such as temperature, dissolved oxygen, cation and anion concentrations, among other factors (Pereira-Silva et al., 2011). A small variation in $\mathrm{pH}$, as observed in this study, may be due to the good buffering capacity of the ecosystem. For the oxidation-reduction potential (ORP, Figure 3), the maximum values that were obtained ranged from 232 (at P1) to $350 \mathrm{mV}$ (at P8). 
ORP influences the water quality by interfering with the respiration of aquatic organisms (Chang; $\mathrm{Ku}$; Yeh, 2014). Our results for the redox potential showed that the different sites of the studied streams had oxidizing conditions because the ORP values were positive.

The median values of the electric conductivity (Figure 3) ranged from 51 (at P1) to $104 \mu \mathrm{S} \mathrm{cm}^{-1}$ (at P3). Maximum values were observed at P3 $\left(287 \mu \mathrm{S} \mathrm{cm}^{-1}\right)$ and at P4 $\left(276 \mu \mathrm{S} \mathrm{cm}^{-1}\right)$. This variable is related to the total concentration of ions and dissolved solids. The highest values were observed at P3 and P4, which can be explained by these points being located after the junction of the streams, so there is a greater movement of particles. CONAMA sets no limits on this variable. However, according to the Environmental Company of São Paulo (CETESB, 2008), values higher than $100 \mu \mathrm{S} \mathrm{cm}^{-1}$ denote an environmental impact.

The highest values for turbidity (Figure 3) were found at points near farms, such as at $\mathrm{P} 7$ and $\mathrm{P} 8$, reaching vales of 41.52 and 45.10 NTU, respectively. Soil misuse and inappropriate occupation and management may increase the water turbidity due to erosion that carries sediment to the water bodies (Lollo; Vivanco, 2014).

The DO concentration should not be below $5.0 \mathrm{mg}$ $\mathrm{L}^{-1}$ according to CONAMA and none of the sampling sites had DO concentrations below $5.0 \mathrm{mg} \mathrm{L}^{-1}$ (Figure 3). DO is an important parameter for the assessment of water quality because many chemical and biological reactions depend directly or indirectly on the DO content, and values below $5 \mathrm{mg} \mathrm{L}^{-1}$ may harm aquatic life (Camas-Anzueto et al., 2015). Maximum values of TDS (Figure 3 ) were observed at P3 (162 mg L-1), P4 (214 $\left.\mathrm{mg} \mathrm{L}^{-1}\right)$ and P5 (153 mg $\left.\mathrm{L}^{-1}\right)$. According to Libânio (2010), as TDS increases, the conductivity also increases. The temperature values showed variations but remained in the range of 17 to $30^{\circ} \mathrm{C}$ (Figure 3), which is coherent with averages taken within the city during the year, where the average air temperature ranged from 19.1 to $25.6{ }^{\circ} \mathrm{C}$ (Rolim, 2014).

\section{Multivariate analysis of chemical and physical variables}

For physical and chemical variables, the principal components resulted in a variable loss from 12 to 4 variables. Temperature and $\mathrm{pH}$ had no significant effects on the total variance explanation, so they were not used. Table 1 shows the eigenvectors that are the newly acquired variables that correspond to the four principal components, obtained in growing order of maximum variance, with greater variability from the original data retained by the first components (PC1 and PC2).
Table 1: Eigenvectors and the correlation between each principal component and the physical and chemical variables studied.

\begin{tabular}{|c|c|c|c|c|}
\hline Variables & PC1 & PC2 & PC3 & PC4 \\
\hline TP & $0.887 *$ & -0.318 & -0.05 & 0.059 \\
\hline COD & $0.832 *$ & -0.293 & -0.015 & 0.142 \\
\hline $\mathrm{NO}_{2}^{-}$ & $0.798 *$ & 0.043 & -0.267 & 0.219 \\
\hline ORP & $0.527 *$ & -0.242 & 0.338 & -0.209 \\
\hline $\mathrm{NO}_{3}^{-}$ & $0.553^{*}$ & $-0.589 *$ & 0.223 & 0.193 \\
\hline COND & 0.466 & $0.764 *$ & 0.264 & 0.155 \\
\hline TDS & 0.509 & $0.764^{*}$ & 0.154 & 0.235 \\
\hline TURB & 0.01 & 0.113 & $-0.711 *$ & -0.188 \\
\hline DO & -0.118 & -0.349 & 0.661 * & -0.213 \\
\hline SRP & 0.029 & 0.233 & $0.637 *$ & -0.455 \\
\hline $\mathrm{Cl}-$ & $0.576 *$ & 0.307 & 0.016 & $-0.588^{*}$ \\
\hline $\mathrm{NH}_{4}^{+}$ & 0.336 & -0.081 & -0.523 & $-0.613^{*}$ \\
\hline
\end{tabular}

${ }^{*}$ Discriminatory values; $\mathrm{PC}=$ principal components; total phosphorus (TP); chemical oxygen demand (COD); oxidationreduction potential (ORP); electric conductivity (COND); total dissolved solids (TDS); turbidity (TURB); dissolved oxygen (DO); soluble reactive phosphorus (SRP).

The first principal component explains most of the total variability data; the second accounts for the largest remaining data variability and it is not correlated with the first. The third component explains the greater variability in the total remaining data not correlated with the first and second components and so on, until the number of principal components obtained in the analysis was reached (Guedes et al., 2012).

The eigenvectors are considered to be a measure of the importance of each variable, and the positive or negative signs indicate that the relationships are directly or inversely proportional, respectively. Coefficients with values above 0.5 were assigned to attributes, whether positive or negative. It is noteworthy that all variables have correlations higher than 0.5 or lower than -0.5 for any of the four main components, and TP and COD showed correlations above 0.8 , which is important to represent water quality. Figure 4 displays the plane formed by two principal components (PC1 and PC2), whereby it is noted that the sum of the retained variability of these components explains $47.54 \%$ of the original variability, while $\mathrm{PC} 1$ and $\mathrm{PC} 2$ were retained individually at $30.41 \%$ and $17.13 \%$, respectively.

A biplot (Figure 4), which is the projection on a two-dimensional plane, aims to identify the behavior of variables, observe associations between the sample points 
and identify variables that are strongly related to each sampling date and point. Samples toward the direction of the variables exhibit higher values, while in the opposite direction the values are smaller. Samples on the ends of the plane have specific characteristics that are different from the other samples and samples that are closer to the center are more similar.

Thus, D4P3 and D4P5 are related to higher COND and TDS. D5 and D6 are different from the others because they are away from each other within the plane. In this way, the variables more closely related to D6, except at $\mathrm{P} 1$ and $\mathrm{P} 2$, were COND, TDS, $\mathrm{Cl}^{-}$and $\mathrm{NO}_{2}^{-}$. The variables closely related to D5, as well as at $\mathrm{P} 1$ and $\mathrm{P} 2$, were TP, COD, ORP and $\mathrm{NO}_{3}^{-}$. The highest concentrations of $\mathrm{NO}_{2}^{-}$were found for $\mathrm{D} 6$ and the highest values for TP, $\mathrm{COD}$ and $\mathrm{NO}_{3}^{-}$were for D5. The lowest concentrations were found for TP on D3, which was in the opposite direction of this variable. Therefore, it is noteworthy that the D5 and D6 samplings were the most distant from the other samplings because they had the highest values for the variables studied. This difference may have occurred because the D5 (in October, rainfall of $46.8 \mathrm{~mm}$ ) and D6 (in December, rainfall of $150.3 \mathrm{~mm}$ ) samplings were carried out in months of high rainfall and after severe drought. Thus, the rain may have washed the surface of the urban and rural areas, dragging compounds and particles to the streams through leaching or erosion processes.
$\mathrm{P} 1$ and $\mathrm{P} 2$ are in opposite directions from the studied variables, presenting the lowest values. However, these points are less impacted. Upstream of P1 there is an industry and sugarcane farm, but P1 is located at the source of the Jaboticabal stream, which has the protection of being a permanent preservation area. Upstream of P2 there is a sugarcane farm, but there is a large drainage network too, so $\mathrm{P} 2$ receives a high volume of water, so it has high water flow and suffers dilution. In this sense, based on principal component analysis, we can state that there was a separation of sampling dates, and P1 and P2 had less influence. This is shown in Figure 4, where P1 and $\mathrm{P} 2$ are located opposite of the direction of the arrows for the variables.

This disparity among points can also be observed on D3P1, which was at the end, far from the D3P8 sample, making them distinct and showing a drastic rise in the concentration values in the direction of $\mathrm{P} 8$. This change of location in the biplot projection shows that from P1 (located at the source of the Jaboticabal stream) until the last sampled point ( $\mathrm{P} 8)$ there was an increase in the values of the variables. These results suggest that the last point was influenced by the points upstream and also by the activities carried out in its surroundings, from which it receives urban and rural influences. Thus, we can also assert that anthropogenic activities can affect water quality by increasing the concentration of some variables.

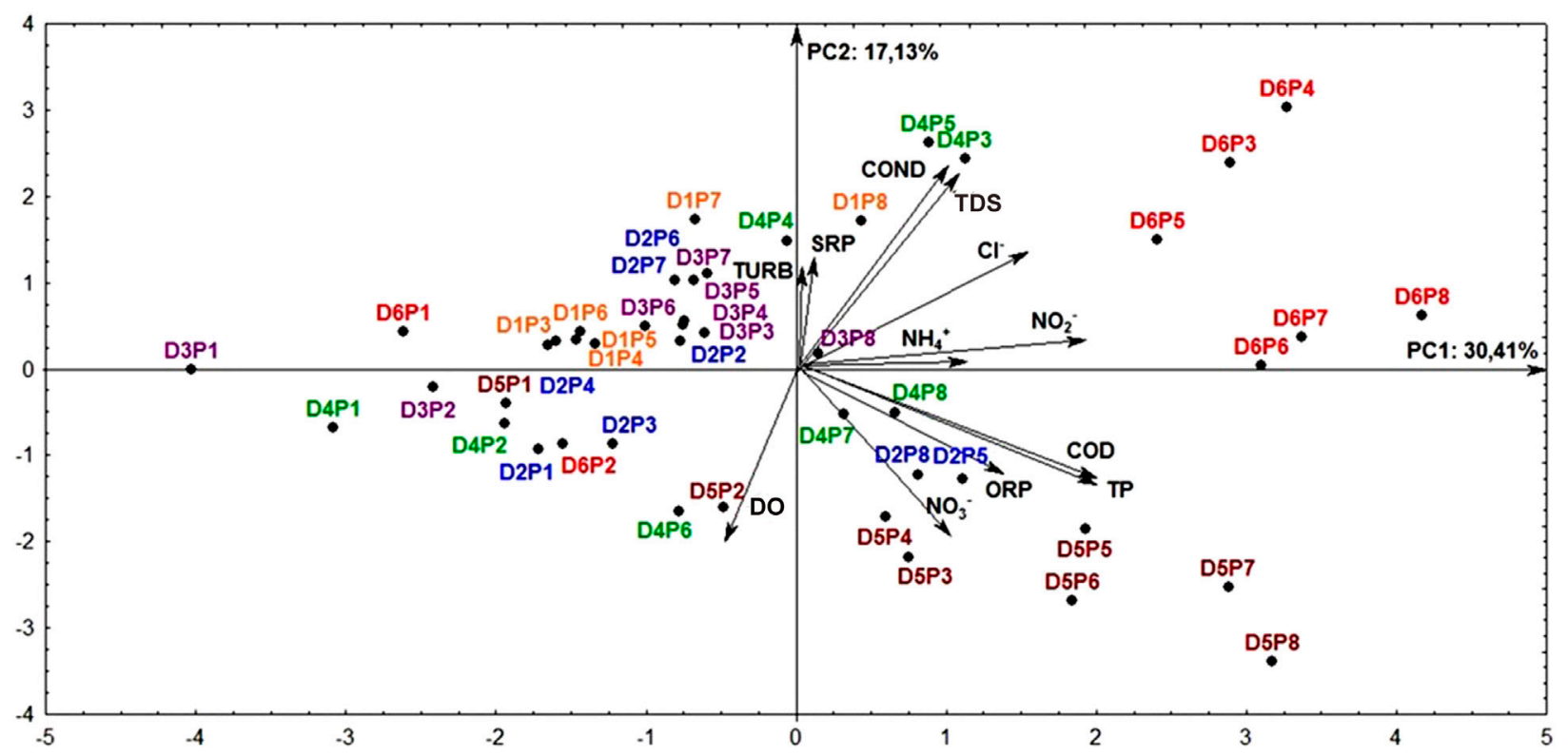

Figure 4: Spatial projection of the first two principal components with a biplot related to the physical and chemical variables of the sampled dates and sites. 


\section{Microbial metabolic profile}

EcoPlate Biolog ${ }^{\mathrm{TM}}$ analysis was first described by Garland and Mills (1991). This methodology compares the use of different carbon sources and is generally used in studies on bacterial communities in various environments such as soil, sludge, fresh water, sediments, biofilms and several other environments (Oliveira et al., 2009; Salomo; Munch; Roske, 2009; Medihala et al., 2012; Gryta; Frac; Oszust, 2014; Patel et al, 2014; Flores-Rentería et al., 2016). By knowing the potential of this method to compare microbial communities in various environments, we opted to use it to measure the ability of bacteria to metabolize different sources of carbon as a comparison tool for water samples.
The calculated values of S, AWCD, $\mathrm{H}$ and $\mathrm{E}$ are useful to describe the activity and diversity of microbial populations and the results are presented in Table 2. In light of these values, we can infer that the microbial population appears not to be altered significantly in the streams when analyzed under the metabolic aspect. Most of the samples can metabolize 28 to 31 carbon sources (S) and the AWCD ranged from 1.12 to 1.62, which shows good behavior on the EcoPlate. The D3P4, D4P3 and D6P3 points had different behaviors, in these samples the values of S and AWCD were approximately $50 \%$ smaller than for the other points. However, when we analyzed the diversity index, we noted similarities among all of the points. This index ranged from 3.23 to 3.42 and $\mathrm{E}$ changed only in the points

Table 2: Substrate richness (S), Average Well Color Development (AWCD), Shannon diversity index (H) and Shannon Evenness index (E) calculated using the EcoPlate data at the sampling times (D1 to D6) and at the sampling points (P1 to P8) that were studied.

\begin{tabular}{|c|c|c|c|c|c|c|c|c|c|}
\hline Collecting & Attributes & P1 & P2 & P3 & P4 & P5 & P6 & P7 & P8 \\
\hline \multirow{4}{*}{ D1 } & $S$ & * & * & 30 & 30 & 30 & 30 & 30 & 30 \\
\hline & AWCD & * & * & 1.5 & 1.5 & 1.59 & 1.49 & 1.62 & 1.48 \\
\hline & $\mathrm{H}$ & * & * & 3.37 & 3.37 & 3.35 & 3.37 & 3.37 & 3.34 \\
\hline & $\mathrm{E}$ & * & * & 0.99 & 0.99 & 0.98 & 0.99 & 0.99 & 0.98 \\
\hline \multirow{4}{*}{ D2 } & S & 31 & 30 & 28 & 29 & 31 & 30 & 29 & 28 \\
\hline & AWCD & 1.48 & 1.54 & 1.33 & 1.48 & 1.45 & 1.4 & 1.4 & 1.24 \\
\hline & $\mathrm{H}$ & 3.42 & 3.37 & 3.34 & 3.32 & 3.41 & 3.34 & 3.38 & 3.35 \\
\hline & $\mathrm{E}$ & 0.99 & 0.99 & 1.0 & 0.99 & 0.99 & 0.98 & 1.0 & 1.01 \\
\hline \multirow{4}{*}{ D3 } & $S$ & 30 & 28 & 30 & 15 & 29 & 29 & 29 & 29 \\
\hline & AWCD & 1.49 & 1.12 & 1.48 & 0.65 & 1.29 & 1.15 & 1.36 & 1.32 \\
\hline & $\mathrm{H}$ & 3.33 & 3.23 & 3.33 & 3.26 & 3.28 & 3.27 & 3.31 & 3.28 \\
\hline & $\mathrm{E}$ & 0.98 & 0.97 & 0.98 & 1.2 & 0.97 & 0.98 & 0.98 & 0.97 \\
\hline \multirow{4}{*}{ D4 } & $S$ & 29 & 28 & 13 & 30 & 31 & 31 & 21 & 30 \\
\hline & AWCD & 1.26 & 1.16 & 0.93 & 1.37 & 1.34 & 1.16 & 1.0 & 1.41 \\
\hline & $\mathrm{H}$ & 3.33 & 3.30 & 3.40 & 3.37 & 3.40 & 3.41 & 3.33 & 3.37 \\
\hline & $E$ & 0.99 & 0.99 & 1.33 & 0.99 & 0.99 & 0.99 & 1.1 & 0.99 \\
\hline \multirow{4}{*}{ D5 } & $S$ & 28 & 30 & 31 & 31 & 30 & 30 & 30 & 29 \\
\hline & AWCD & 1.22 & 1.37 & 1.33 & 1.38 & 1.18 & 1.32 & 1.57 & 1.38 \\
\hline & $\mathrm{H}$ & 3.35 & 3.30 & 3.39 & 3.37 & 3.39 & 3.39 & 3.38 & 3.35 \\
\hline & $E$ & 1.01 & 0.97 & 0.99 & 0.98 & 1.0 & 1.0 & 0.99 & 1.0 \\
\hline \multirow{4}{*}{ D6 } & $S$ & 30 & 29 & 16 & 29 & 29 & 30 & 31 & 31 \\
\hline & AWCD & 1.59 & 1.37 & 1.01 & 1.21 & 1.24 & 1.55 & 1.56 & 1.51 \\
\hline & $\mathrm{H}$ & 3.35 & 3.25 & 3.35 & 3.36 & 3.35 & 3.36 & 3.36 & 3.38 \\
\hline & $E$ & 0.99 & 0.97 & 1.21 & 1.0 & 0.99 & 0.99 & 0.98 & 0.98 \\
\hline
\end{tabular}

*Have not been conducted. 
where $\mathrm{S}$ was low. These results suggested a great and conserved diversity at the study sites.

Recent studies in a water reservoir in China (Yang; Huang; Zhang, 2015) showed the effect of thermal stratification on bacterial communities. The authors explored the functional diversity and bacterial community composition using the Biolog method and 16S rRNA-based 454 pyrosequencing. The results showed a variation ( 0.3 to $0.6)$ in the color development index (AWCD) and a small variation in the Shannon diversity index (approximately 3 ) for the studied stratification. Molecular studies of bacterial diversity were consistent with the carbon consumption data, confirming the interference of thermal stratification in the bacterial community in the water.

The functional diversity, understood in our study to be the utilization of carbon sources in the Biolog EcoPlates, showed no differences among samples. In general, the investigated samples were characterized by the different utilization pattern of the five guilds. The five guilds of the carbon substrates proposed by Weber and Legge (2009) were used: 1) carbohydrates, 2) carboxylic and acetic acids, 3) amino acids, 4) polymers, and 5) amines and amides. To compare the water population in the samples, the corrected absorbance values of the substrates were summarized and expressed as a percentage of the total absorbance value of the plate for each guild. All of the water samples showed the same results for the use of different carbon sources. This relationship was similar for all of the data collection points. Furthermore, the insignificant differences among the AWCDs (Table 2) manifested the equivalent potential of microbes to use a set of naturally relevant carbon sources in all of the studied samples.

Heterotrophic bacteria more intensively utilized carboxylic and acetic acids and carbohydrates, which are intermediates for organic matter degradation ( $\mathrm{Li}$ and $\mathrm{Yu}, 2010$ ). The high or low catabolic capacity that was observed in a sample may refer to a high number of heterotrophic bacteria, and change in the community composition. The physical and chemical parameters studied in the samples were not so different, and there were nutrients in adequate concentrations in the environment. Therefore, it was not difficult to suggest that the bacterial population of the studied streams was not undergoing changes due to anthropogenic activities. On the other hand, we noted a slight increase in the metabolic capacity of polymers (data not shown). This increase in activity appeared at points 3 to 8 , referring to the urban (3-5) and agricultural (6-8) areas where the Jaboticabal stream flows.

These data can be important considering the results presented by Freixa and Romani (2014). Based on the chemical analysis results in our work, we cannot say that we studied a highly polluted stream. However, we noticed a suggestive rise in some of the chemical components along the watercourse during the analyzed period. This may suggest the interference of human activities on water quality in urban and rural environments even with basic sanitation care being applied in the area. These authors showed that the EcoPlate was useful to detect changes in the microbial functional fingerprint in fresh sediment along a river pollution gradient. The microbial community from the upstream site was able to metabolize more labile substrates than the downstream sediment community. The functional fingerprint analysis clearly distinguished the sediment microbial communities from the most polluted sites downstream, which showed a potential capacity to use more complex carbon substrates such as polymers.

The Biolog EcoPlates were proven to effectively differentiate between the microbial communities based on the carbon metabolism, and this methodology can be used as an important ecological indicator of changes in the ecosystem. Thus, in our work we decided to compare the metabolic profile of the microbial populations of each sample based on the consumption of several carbon sources. This comparative study was conducted using a cluster analysis and the construction of a heatmap (Figure 5). The score in this analysis represented the difference between the consumption of each sample for the same substrate. The biggest consumption was shown by the red color and the lowest consumption was represented by the yellow color. The black color represented a similar use of the substrate. Through the heatmap shown in Figure 5, we observed the formation of two hierarchical groups for all of the sampled times and points. One of these groups comprised the sampled points (A) and the other was from the consumption of the substrates (B).

For the first group (A), we noted that the samples were grouped into three clusters $(\mathrm{a}, \mathrm{b}, \mathrm{c})$ and they were not correlated among the point or date collections. The other group (B) showed four clusters (1, 2, 3 and 4). Cluster 1 was formed by the least consumed substrates group. In cluster 2, we noted the highest amount of consumed carbon sources followed by cluster 4 . Cluster 3 comprises a number of substrates that were most differentiated from the water samples that were studied. This group was composed of three carboxylic and acetic acids (4-hydroxy Benzoic acid, D-Malic acid, and D-Glucosaminic acid), one polymer (Tween 40), one amino acid (L-Arginine), and the Putrecine; however, the metabolic profile was similar for all of the points and collection times. The default in the metabolic profiles showed similar functionality (based on the consumption of different sources of carbon) among the sampled points along the streams. 


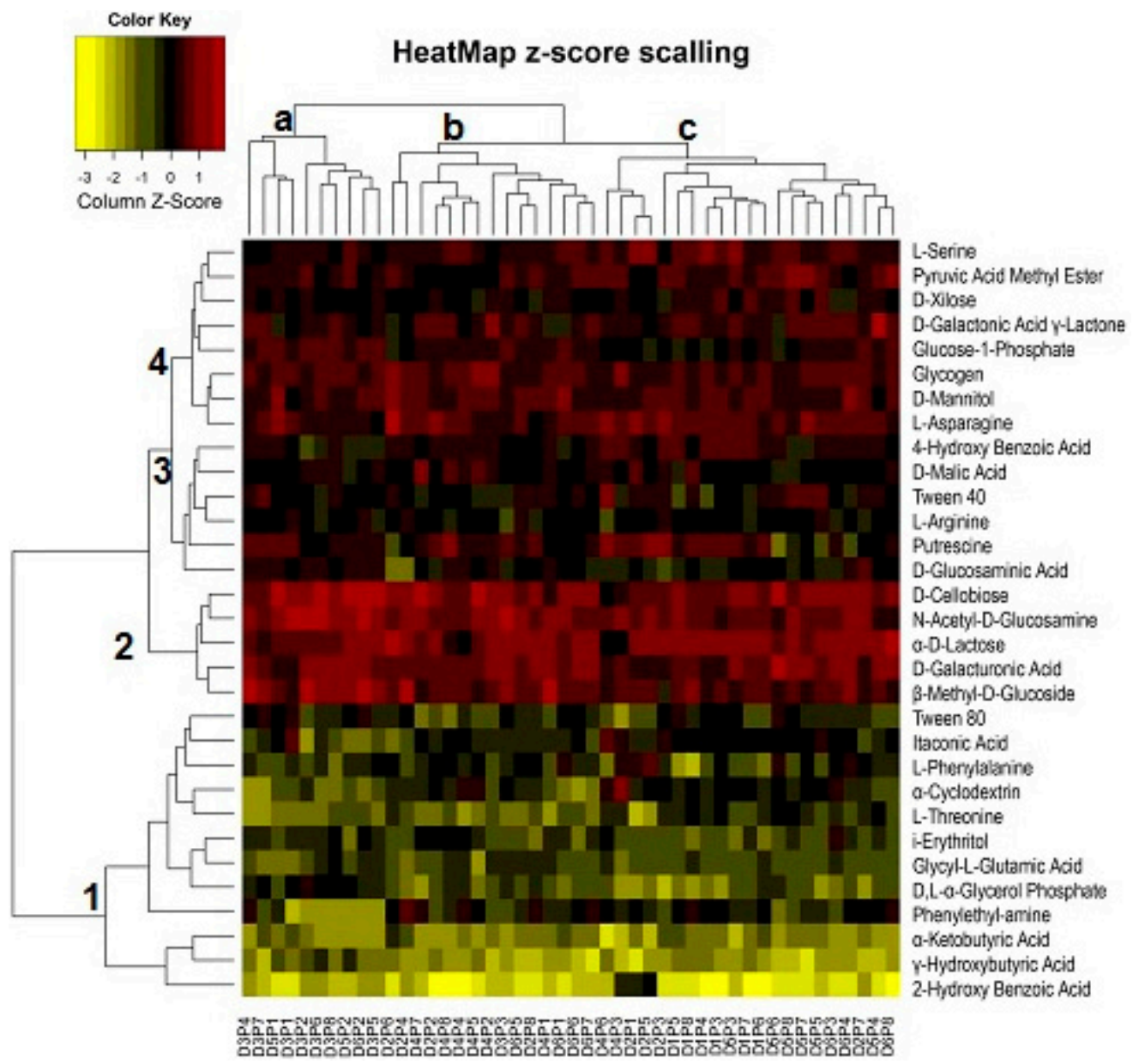

Figure 5: Heatmap for the water samples using 31 carbon sources by the Biolog EcoPlate.

\section{CONCLUSIONS}

Our results showed elevated values of TP and COD in the water bodies with higher values at sites (P6, P7 and P8) near agricultural areas compared to urban areas. The last three sampling sites were downstream of the urban area where, despite the existence of a sewage disposal system, the results of the chemical analyses indicated the possibility of the clandestine discharge of wastewater in the studied streams and the influence of soil agricultural. For the metabolic analysis of the microbial population in the different samples from our study, we observed that there was no relationship for the EcoPlate methodology results regarding farming or urban activities. The hierarchical clustering method enabled the observation of differences among the sampling dates regardless of the sample point or collection time. The diversity index was similar at the different sampling points depending on the type of substrate that was consumed. Our results did not allow us to state that the urban and agricultural areas were or were not interfering significantly with the functionality of the microbial population of the water sources that were studied, but there was strong evidence for this interference. To address these issues, further studies need to be performed at these locations, such as the use of molecular techniques for identification and quantification of the constituent organisms at the different study sites as well as the microbial population in the stream sediments.

\section{ACKNOWLEDGMENTS}

The authors acknowledge the Program of Agricultural Microbiology FCAV/UNESP Campus Jaboticabal and Coordenação de Aperfeiçoamento de Pessoal de Nível Superior (CAPES) for providing a PROAP master's scholarship. 


\section{REFERENCES}

ASKEW, E. F.; SMITH, R. K. Inorganic nonmetallic constituents. In: EATON, A. D. et al. Standard methods for the examination of water \& wastewater. 21. ed. Washington, DC: American Public Health Association, APHA. 2005. p. 1-192.

BAIRD, R. B. Aggregate organic constituents. In: EATON, A. D. et al. Standard methods for the examination of water \& wastewater. 21. ed. Washington, DC: American Public Health Association, APHA. 2005. p. 1-74.

BAKER, M. L. Introduction. In: EATON, A. D. et al. Standard methods for the examination of water \& wastewater. 21. ed. Washington, DC: American Public Health Association APHA. 2005. p. 1-56.

BORGES, M. J; GALBIATI, J. A; FERRAUDO, A. S. Monitoramento da qualidade hídrica e eficiência de interceptores de esgoto em cursos d'água urbanos da bacia hidrográfica do córrego Jaboticabal. Revista Brasileira de Recursos Hídricos. 8(2):161-171, 2003.

BRASIL. Ministério do Meio Ambiente. Conselho Nacional do Meio Ambiente. Resolução CONAMA No 357/2005, de 17 março de 2005. Available in: <http://www.mma. gov.br/port/conama/res/res05/res35705.pdf>. Access in: October, 20, 2015.

CAMAS-ANZUETO, J. L. et al. Sensitive layer based on Lophine and calcium hydroxide for detection of dissolved oxygen in water. Measurement. 68:280-285, 2015.

Companhia Ambiental do Estado de São Paulo - CETESB. Relatório de qualidade das águas interiores no Estado de São Paulo. 2008. (Série Relatórios). Available in: <http://www. cetesb.sp.gov.br/userfiles/file/agua/aguas-superficiais/ aguasinteriores/variaveis/aguas/variaveis_quimicas/ condutividade.pdf>. Access in: September, 10, 2015.

CHANG, Y. H.; KU C. R.; YEH, N. Solar powered artificial floating island for landscape ecology and water quality improvement. Ecological Engeneering. 69:8-16, 2014.

DIAS, S. G.; SIPAÚBA-TAVARES, L. H. Physical, chemical and microbiological aspects during the dry and rainy seasons in a pond covered by macrophyte used in aquaculture water supply. Acta Limnologica Brasiliensia. 24:276-284, 2012.

FLORES-RENTERÍA, D. et al. Agricultural matrix affects differently the alpha and beta structural and functional diversity of soil microbial communities in a fragmented Mediterranean holm oak forest. Soil Biology \& Biochemistry. 92:79-90, 2016 .
FREIXA, A.; ROMANÍ, A. M. Shifts in carbon substrate utilization in sediment microbial communities along the Llobregat River. Fundamental and Applied Limnology. 185(34):247-262, 2014

GARLAND, J. L.; MILLS, A. L. Classification and characterization of heterotrophic microbial communities on the basis of patterns of community-level sole-carbon-source utilization. Applied and Environmental Microbiology. 57(8):23512359, 1991.

GRYTA, A.; FRAC, M.; OSZUST, K. The application of the biolog EcoPlate approach in ecotoxicological evaluation of dairy sewage sludge. Applied Biochemistry and Biotechnology. 174(4):1434-1443, 2014.

GUEDES, H. A. S. et al. Aplicação da análise estatística multivariada no estudo da qualidade da água do Rio Pomba, MG. Revista Brasileira de Engenharia Agrícola e Ambiental. 16(5):558-563, 2012

HACKETT, C. A.; GRIFFITHS, B. S. Statistical analysis of the time-course of Biolog substrate utilization. Journal of Microbiological Method. 30(1):63-69, 1997.

JABEEN, S. et al. Physico-chemical parameters of surface and ground water and their environmental impact assessment in the Haripur Basin, Pakistan. Journal of Geochemical Exploration. 138:1-7, 2014

JACKSON, D. A. Stopping rules in principal components analysis: A comparison of heuristical and statistical approaches. Ecology. 74(8):2204-2214, 1993.

JALOWIECKI, L. et al. Microbial community profiles in wastewaters from onsite wastewater treatment systems technology. PLoS ONE. 11(1):1-15, 2016.

JIAN, L. et al. Phosphorus losses via surface runoff in Rice-wheat cropping systems as impacted by rainfall regimes and fertilizer applications. Journal of Integrative Agriculture. 15(3):667-677, 2016.

LIBÂNIO, M. Fundamentos de qualidade e tratamento de água. 3. ed. Campinas, SP: Editora Átomo, 2010. 494 p.

LOLLO, J. A.; VIVANCO, J. M. C. Erosion processes and water quality in Caçula Stream Watershed (Ilha Solteira - SP, Brazil). Engineering Geology for Society and Territory. 3:411-416, 2014

MEDIHALA, P. G. et al. Effect of pumping on the spatio-temporal distribution of microbial communities in a water well field. Water Research. 46(4):1286-1300, 2012 
MUNIZ, S. et al. Analysis of the diversity of substrate utilisation of soil bacteria exposed to $\mathrm{Cd}$ and earthworm activity using aeneralised additive models. PLoS ONE. 9(1):1-10, 2014.

OLIVEIRA, C. A. de et al. Diversidade bacteriana da rizosfera de genótipos de milho contrastantes na eficiência de uso de fósforo. Pesquisa Agropecuária Brasileira. 44(11):14731482, 2009.

PATEL, M. et al. Assessment of ground water quality with respect to bacteriological contamination in Bhavnagar, Gujarat, India Clean. Soil Air Water. 42(10):1351-1362, 2014.

PEREIRA-SILVA, E. F. L. et al. Avaliação da qualidade da água em microbacias hidrográficas de uma Unidade de Conservação do Nordeste do estado de São Paulo, Brasil. Brazilian Journal of Biosciences. 9(3):371-381, 2011.

PISSARRA, T. C. T. et al. Informações básicas para o planejamento ambiental: Município de Jaboticabal. 1. ed. Jaboticabal: FUNEP, 2009. v.1. 70 p.

ROLIM, G. S. Dados estação convencional: dados meteorológicos mensais. Jaboticabal, SP: FCAV/UNESP, 2014. Available in: <http://www.fcav.unesp.br/\#!/estacaoagroclimatologica/dados/estacao-convencional/>. Access in: May, 13, 2016.

SAHU, B. L. et al. Evaluation of significant sources influencing the variation of physico-chemical parameters in Port Blair
Bay, South Andaman, India by using multivariate statistics. Marine Pollution Bulletin. 66(1-2):246-251, 2013.

SALOMO, S.; MUNCH, C.; ROSKE, I. Evaluation of the metabolic diversity of microbial communities in four different filter layers of a constructed wetland with vertical flow by Biolog ${ }^{\mathrm{TM}}$ analysis. Water Research. 43(18):4569-4578, 2009.

SHARPLEY, A.; WANG, X. Managing agricultural phosphorus for water quality: Lessons from the USA and China. Journal of Environmental Sciences. 26(9):1770-1782, 2014.

SULAIMAN, R. et al. Comparative study of trends of nitrate, chloride and phosphate concentration levels in selected urban rivers. Measurement. 55:74-81, 2014.

WEBER, K. P. et al. Data transformations in the analysis of community-level substrate utilization data from microplates. Journal of Microbiological Methods. 69(3):461-469, 2007.

YANG, X.; HUANG, T.; ZHANG, H. Effects of seasonal thermal stratification on the functional diversity and composition of the microbial community in a drinking water. Reservoir Water. 7(10):5525-5546, 2015.

ZHANG, $H$. et al. Microbial community functional diversity and enzymatic activity in the sediments of drinking water reservoirs, Northwest China. Desalination Water Treament. 52(7-9):1608-1614, 2014. 